\title{
Transcultural validation of an instrument to evaluate Advanced Nursing Practice competences in Brazil
}

\author{
Validação transcultural de instrumento de avaliação de competências de Prática Avançada de Enfermagem para o Brasil \\ Validación transcultural de instrumento de evaluación de competencias de Enfermería de Práctica Avanzada para Brasil
}

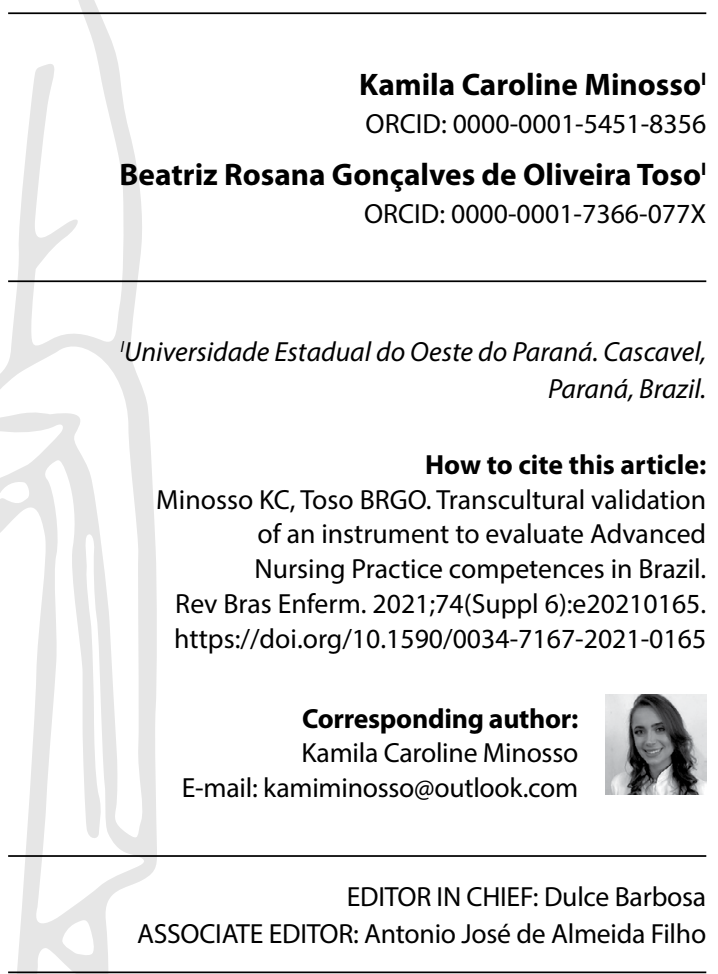

Submission: 03-09-2021
Approval: 03-23-2021

\begin{abstract}
Objectives: to carry out a transcultural validation of the Modified Advanced Practice Nursing Role Delineation Tool for the Brazilian language. Methods: methodological and quantitative study, including the process of translation and cultural adaptation of the instrument. The committee of evaluators was formed by seven experts. Data collection for the pre-test took place from November 2020 to January 2021, with 30 nurses from the West of Paraná. Data analysis used Cronbach's alpha, intraclass correlation, and kappa. Results: the agreement of the evaluator committee reached a substantial kappa of 0.68 and an intraclass correlation of 0.80 , and as a result, the version for application in a pretest was approved. The pretest found a 0.98 Cronbach's Alpha and an intraclass correlation of 0.61 . Conclusions: the instrument was found to be culturally adapted and can be used in the country to identify the competences of the Primary Healthcare Nurses to develop advanced nursing practices.

Descriptors: Advanced Practice Nursing; Validation Studies; Professional Competence; Primary Health Care; Public Health Nursing.
\end{abstract}

\section{RESUMO}

Objetivos: realizar a validação transcultural da Modified Advanced Practice Nursing Role Delineation Tool para a língua portuguesa brasileira. Métodos: estudo metodológico, quantitativo, com processo de tradução e adaptação cultural da ferramenta. O comitê de juízes foi composto por sete experts. A coleta de dados do pré-teste ocorreu de novembro de 2020 a janeiro de 2021 com 30 enfermeiros de um município do oeste do Paraná. A análise dos dados foi realizada pelo alfa de Cronbach, correlação intraclasse e kappa. Resultados: no comitê de juízes, o kappa obteve concordância substancial de 0,68 e correlação intraclasse de 0,80 , sendo aprovada a versão para aplicação no pré-teste; neste, obteve-se alfa de Cronbach de 0,98 e correlação intraclasse de 0,61 . Conclusões: essa ferramenta foi considerada adaptada culturalmente e pode ser utilizada no país com vistas a identificar as competências dos enfermeiros da Atenção Primária para o desenvolvimento de práticas avançadas de enfermagem.

Descritores: Prática Avançada de Enfermagem; Estudo de Validação; Competência Profissional; Atenção Primária à Saúde; Enfermagem em Saúde Pública.

\section{RESUMEN}

Objetivos: realizar validación transcultural de la Modified Advanced Practice Nursing Role Delineation Tool a la lengua portuguesa brasileña. Métodos: estudio metodológico, cuantitativo, con proceso de traducción y adaptación cultural de la herramienta. Comité de jueces compuesto por siete expertos. Recogida de datos del pre-test ocurrió de noviembre de 2020 a enero de 2021 , con 30 enfermeros de un municipio del oeste de Paraná. Análisis de datos realizado por alfa de Cronbach, correlación intraclase y kappa. Resultados: en el comité de jueces, el kappa obtuvo concordancia sustancial de 0,68 y correlación intraclase de 0,80 , siendo aprobada la versión para aplicación en el pre-test; en esto, obtuvo alfa de Cronbach de 0,98 y correlación intraclase de 0,61. Conclusiones: esa herramienta fue considerada adaptada culturalmente y puede ser utilizada en el país con objetivo de identificar las competencias de los enfermeros de la Atención Primaria para el desarrollo de enfermería de prácticas avanzadas.

Descriptores: Enfermería de Práctica Avanzada; Estudio de Validación; Competencia Profesional; Atención Primaria de Salud; Enfermería en Salud Pública. 


\section{INTRODUCTION}

As society evolves, its setting and the health needs of the population change, becoming more complex. Aging, the increase in the number of chronic and impairing diseases, and a higher life expectancy generate the need to find new ways to address these phenomena ${ }^{(1)}$.

Brazilian nursing is going through growing changes, a restructuring of the role of its professionals in Primary Health Care $(\mathrm{PHC})$, which is based on a broad and effective nursing care ${ }^{(2)}$.

Among the innovations in health care, there is a discussion about broadening the scope of the nurse's role, which has been ongoing for more than 50 years in the countries that are part of the Economic Cooperation and Development (OECD). This idea has been encouraged in the region of Latin America and the Caribbean, as a response to the need to increase human resources and widen the access to PHC and its ability to deal with situations. In this region, this discussion is anchored on the resolution from the United Nations to advance the goal Universal Health Coverage (UHC) and to increase the problem-solving capabilities of PHC units. The discussion was brought forth in 2014 by the Pan American Health Organization (PAHO) Executive Committee ${ }^{(3-4)}$.

Therefore, aiming to increase the access to health services and their problem-solving capabilities, the PHC is being changed, and the nurses of many countries have adopted the role of Advance Practice Nursing (APN). Studies have shown that APN started in the United States, responding to a series of sociopolitical situations which meant that nursing professionals had to assume responsibility over new situations. From the 1950s on, within the hospitals, the Clinical Nurse Specialists (CNS) were created, and later, in 1960, the Nurse Practitioners (NP) were brought into Primary Care. This had repercussions, and the role was implemented in European countries such as the United Kingdom, the Netherlands, and Nordic Countries ${ }^{(4-5)}$.

The scope of APN roles is varied around the world, which makes it more difficult to have a deep understanding of it. The APN can be seen as an innovative element, since it aids in the process of improving the health care to more vulnerable populations, those with physical deficiency, chronic diseases, and others. Furthermore, it contributes to qualify care practices to prevent, promote, and rehabilitate health at many points in the care network ${ }^{(6)}$.

When the APNs are well-established, they generally work in two modalities: either with nurses replacing the physicians in Primary Care, or with them complementing clinical work, partnering with the team in the PHUs ${ }^{(7-8)}$. However, as opposed to what happens in many countries where the APN is already implanted and consolidated, in Latin America and the Caribbean there are scare discussion and researches about the theme ${ }^{(4)}$.

In Brazil, from 2015 on, representatives of the Federal Council of Nursing (Cofen) and from the Brazilian Association of Nursing (ABEn) met with representatives from the Brazilian Ministry of Health at the headquarters of PAHO to discuss strategies to implement the APN in the Brazilian context ${ }^{(9)}$. Over the last few years, there have been discussions, and the PAHO developed strategies to give support to the country in this process, making it a possibility ${ }^{(6)}$.

The accumulated evidence often shows that these professionals provide high-quality and safe services, and can diminish the cost of health care ${ }^{(8)}$. Corroborating this, a scoping review showed that the implementation of APNs has a positive impact in patient care with regard to health outcomes, quality of life, satisfaction, cost for money, and more accessibility to health services ${ }^{(1)}$.

On the other hand, studies on the APN in Brazil are incipient, and the few that exist are literature reviews that aim to understand the function better, especially regarding its role in Primary Care. For this purpose, a valid and reliable instrument would help to carry out investigations about the activity of Brazilian nurses, aiming to point out, in their actions, the competences of advance practice nurses, identifying and defining their role in the services. To aid in this process, aiming to implement and effectively develop APN, a systematic procedure is needed, one based on evidence, including the collection of any relevant data about the needs and requirements of the profession.

Although, in Brazil, there are still no specific instruments that can aid to identify APN functions, certain instruments have been used abroad. The tools used in this practice, such as the Modified Advanced Practice Nursing Role Delineation Tool ${ }^{(10)}$, make it possible to delineate nursing roles in advance practices. This instrument has the potential of recognizing, among the actions of the nurse, their competence for APN roles.

Therefore, the main objective of this investigation is to evaluate whether a scale from another context, validated for Brazil, can measure the advanced nursing practices carried out by nurses in Primary Health Care.

\section{OBJECTIVE}

To carry out a cultural adaptation and to validate, for the Brazilian Portuguese language, the Modified Advanced Practice Nursing Role Delineation Tool.

\section{METHODS}

\section{Ethical aspects}

This study was submitted and approved by the Research Ethics Committee from the Universidade Estadual do Oeste do Paraná (UNIOESTE). It followed all ethical and legal requirements for researches involving human beings.

\section{Design and place of study}

This is a methodological and quantitative study, including the process of translation and cultural adaptation of the Modified Advanced Practice Nursing Role Delineation Tool according to the directives of Beaton et al. ${ }^{(11)}$.

The translation, cultural adaptation and validation process (TCAV) is necessary when one wishes to apply a questionnaire in different countries that speak a same language. The TCAV follows a systematic process, similar to that recommended by Beaton et al. ${ }^{(11)}$, including the following stages ${ }^{(12-13)}$.

a) cultural adaptation: direct translation, synthesis, inverse translation, consolidation by an expert committee, and pre-test.

b) validation: evolution of internal consistency, intra- and/or inter-observational reliability, logical or apparent validity, and validity of content, criteria, and construct. 
The cultural adaptation of a questionnaire, instrument or scale to be used in another country, with different cultures and language, require an exclusive methodology, so that equivalence between origin and destine languages can be reached ${ }^{(14)}$.

To do so, some steps must be followed for the process of cultural adaptation of an instrument, which include: 1) translating from the original language to the target one, by two independent translators; 2) synthesizing the translations; 3) back-translation, that is, translating the instrument back to its original language, after what the original and translated versions are compared, and the differences discussed by the researcher and the translators; 4) consolidation of the versions by an evaluative committee, a stage that aims to produce a final version adapted into the language; 5) after the equivalence was analyzed, a pre-final version will be reached and submitted to a pre-test. Any question that generates $15 \%$ or more doubts, or that are not understood, must be reviewed by the evaluative committee and reapplied to the respondents.

Finally, to conclude the cultural adaptation of the instrument, all reports and forms used during the process must be presented to the authors who own the copyrights of the instrument ${ }^{(14)}$.

All stages of this study were carried out online.

\section{Study sample}

Considering that the minimum recommended number of components in the evaluative committee is three ${ }^{(15)}$, nine professionals were selected and invited intentionally using the Lattes Platform from the National Council of Scientific and Technological Development (CNPq). An advanced search by subject was carried out in the platform, considering as inclusion criteria: being a researcher and/or professional in the field of health with expertise in the theme advance nursing practices, excepting translators. The contact was carried out in a letter of invitation sent to the e-mail registered in the platform. From the nine invitees, seven accept participating. The instrument was submitted to the approval to seven specialist judges, six of whom were nurses and one was a professor a course of languages.

Regarding the participants of the pretest, there was a sample of 30 nurses active in the Primary Healthcare of a city in the West of Paraná.

\section{Data collection instrument}

Anne M. Chang, author of the instrument from Queensland University of Technology/Australia, was contacted via e-mail, and was asked for an authorization for the validation of the scale into Brazilian Portuguese and use it in the Brazilian context. She responded positively.

The Modified Advanced Practice Nursing Role Delineation Tool ${ }^{(16)}$ was developed in Australia and is a version of the tool Strong Model of Advanced Practice ${ }^{(17)}$. It can be self-applied or used as an interview tool. It is made up by three sessions. Session A asks for demographic data. Session B is related to APN, identifying 5 domains of practice and 41 items proposed to address the main fields of practice. The titles of these domains are: Direct broad care, System support, Education, Research, and Publication and Professional leadership. Session C, finally, addresses the Domain of practice, which includes the other five domains.
The instrument requests participants to recommend how much time they spend doing each of the activities from a list during their work, marking the corresponding item. The answers for each item are distributed in a 5-point Likert scale (4 - Much time; 3 - Quite some time; 2 - Some time; 1 - Little time; 0 - No time). The score varies from 0 to 164 .

\section{Study protocol}

Initially, two professionals from the field of health, with previous knowledge about the instrument and the theme, translated it. Later, the translated instrument was sent to two bilingual translators who carried out a back translation, leading to a synthesized version to be evaluated by the committee. The Delphi technique was used in this stage ${ }^{(11)}$.

The committee of specialist judges aims to verify whether the translation and back translation process managed to achieve the desired semantic, conceptual, and idiomatic equivalence. That is, if the situations mentioned or reported are culturally viable or understandable to the target population ${ }^{(15)}$, guaranteeing that there is an actual adaptation into Brazilian Portuguese.

The first step was the selection of judges. The professionals were invited to participate as evaluators through the signing of an acceptance and authorization form. Then, they were informed about the objectives, methodology, and justification of the research through a small instructional text. Later, a form to evaluate the instrument was sent via e-mail, to receive the evaluation of the judges about the semantic, idiomatic, cultural, and conceptual equivalence of the instrument, after it was translated into Brazilian Portuguese. There were recommendations for the judges to write down suggestions and comments to improve the words evaluated. The period for the evaluative committee to evaluate the instrument was from July to September, 2020.

The evaluation form of the instrument allowed specialists to analyze each item using a scale with three levels of agreement: "agree", "partially agree", "disagree". There was also a space for the input of suggestions about each item. As a result, the suggestions of the judges were evaluated. Only items about which the agreement of the judges was $90 \%$ or higher in the synthesis version were accepted. The items that did not reach this percentage were sent to the evaluative committee for a new evaluation, after reformulated using the suggestions received, so they could reach $90 \%$ of agreement.

There was a revision of the process of transcultural adaptation as a whole. Based on the analysis, deviations were identified that could indicate the need of adjustment of any item. This is how the pre-final version of the scale was obtained. In all stages of the translation of the instrument, reports were created to describe the process followed. The steps for translation and cultural adaptation are described in Figure 1.

After the scale was validated by the evaluative committee, the instrument was put through a pre-test, which was sent to 54 nurses who work in the Primary Health Care of a city in the West of Paraná, as an on-line form elaborated in the platform Google Forms. It included open and closed questions about the domains and competences of the nurse in Primary Health Care, in accordance with the original instrument. 30 professionals filled in the forms and sent them back. 


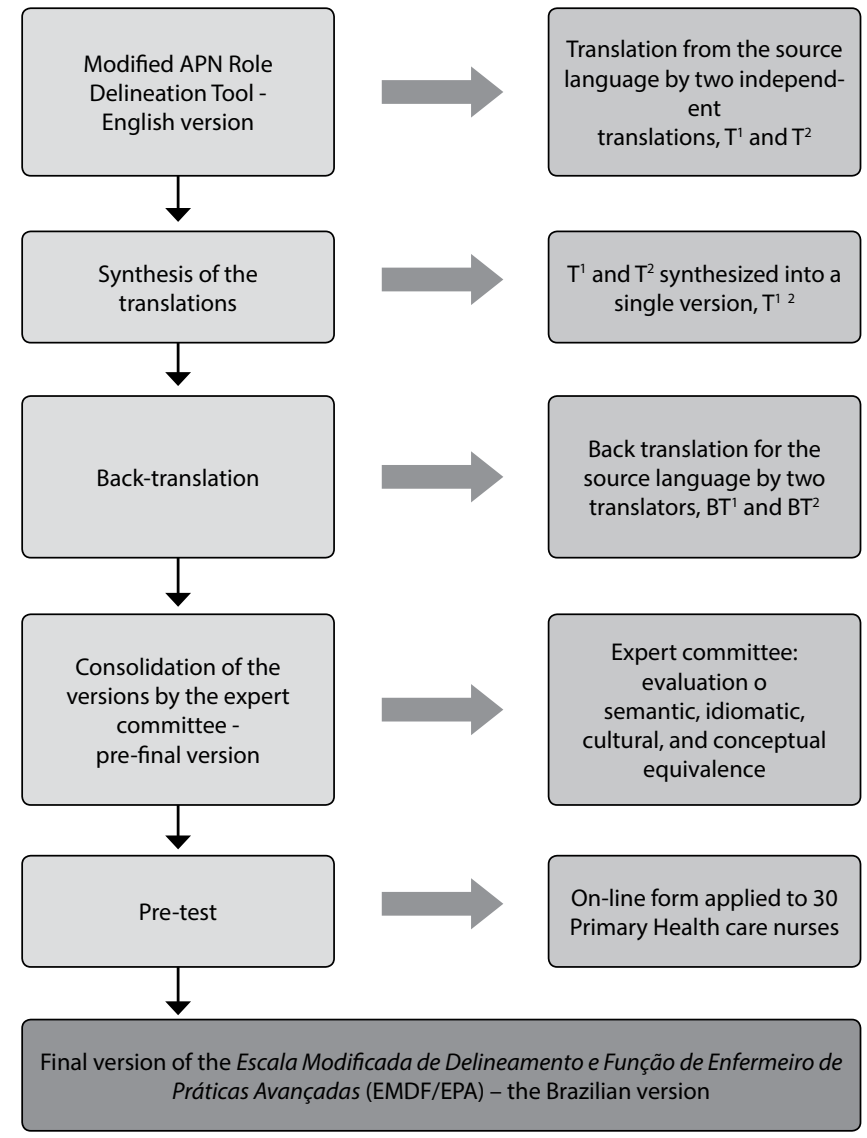

Note: $T 1$ - Translations 1; T2 - Translation 2; BT - Back translation 1;BT 2 - Back translation 2. Figure 1 - Process of translation and cultural adaptation of the Brazilian Version of the Modified Advanced Practice Nursing Role Delineation Tool

The participants had access to a space to leave comments when they wanted to. No item in the form could be left blank, except for the space for comments. Data collection took place from November 2020 to January 2021.

\section{Data analysis}

Regarding statistical analysis, the data was typed in and compiled in an electronic spreadsheet, which was double checked. The agreement of the judges was verified regarding how well the measure represented the content addressed using the Content Validity Index (CVI); concerning the reliability of item agreement, the kappa coefficient, Cronbach's alpha, and the intra-class correlation coefficient were used (ICC). The significance level adopted for all statistical tests was $95 \%$.

\section{RESULTS}

In the first stage of the study, the 46 items that make up the instrument were evaluated by the committee of judges. Regarding the first round of evaluation, Table 1 shows the items whose CVI was above 0.80 , indicating that their content was equivalent. The other items ( $n=19 ; 41.30 \%)$ found low levels of agreement in their CVI index; as a result, they were changed according to the suggestions and a new evaluation was carried out by the committee of judges about the reformulated items.

Table 1 - Values of agreement regarding the Content Validity Index

\begin{tabular}{lcc}
\hline Domains & Questions & CVI \\
\hline 1 - Direct broad care & $1.2 ; 1.4 ; 1.5 ; 1.6 ; 1.8 ; 1.9 ; 1.11 ; 1.13$ & \\
2- System support & $2.1 ; 2.4 ; 2.5 ; 2.6 ; 2.9$ & \\
3 - Education & $3.1 ; 3.2 ; 3.3 ; 3.6$ & \\
4 - Research & $4.1 ; 4.2 ; 4.3 ; 4.6$ & $\geq 0.80$ \\
5 - Publication and & $5.1 ; 5.2 ; 5.4 ; 5.6$ & \\
professional leadership & & \\
Practical domains & D1;D4 & \\
\hline Note: $C V I$ - Content Validity Index; D-Domain. & &
\end{tabular}

The scores of the scale show a good agreement in the first stage, with a kappa of 68.0 and an intraclass correlation of 0.80 .

The reformulated items are presented in Chart 1.

After all reformulations, in the second stage, the instrument found the following results: $\mathrm{CVI}=0.88$; $\mathrm{kappa}=0.83$. All suggestions from the evaluative committee were evaluated and accepted due to being congruent with literature. Table 2 presents the data regarding participant characterization.

In the second stage, the pre-test, the scale was applied to a sample of 30 nurses, most of whom were female $(n=24 ; 80 \%)$ and from 30 to 39 years old $(n=24 ; 80 \%)$. It stands out that more than $80 \%$ of them ( $n=25 ; 83.3$ ) have specialization or lower as their highest educational level. Also, it was found that most acted as clinical/assistance nurses ( $n=13 ; 39.4 \%$ ), but it stands out that they routinely assume the role of coordinators of the health unit. Regarding professional experience, the mean was that of 9 years, with a minimum of 1 year and a maximum of 29 years, according to Table 2 .

Chart 1 - Questions before and after the reformulation carried out according to the suggestions of the evaluative committee

\begin{tabular}{|c|l|l|}
\hline Question & Version after translation and cultural adaptation & $\begin{array}{l}\text { Version after reformulations according to the suggestions } \\
\text { of the judges }\end{array}$ \\
\hline Title & Modified Advanced Practice Nursing Role Delineation Tool & $\begin{array}{l}\text { Modified Advanced Practice Nursing Role Delineation Tool (EMDF/EPA) - } \\
\text { Brazilian version }\end{array}$ \\
\hline $\begin{array}{c}\text { APN } \\
\text { activities }\end{array}$ & $\begin{array}{l}\text { Indicate how much time you would spend in the following } \\
\text { activities, in your current role, by signing the corresponding } \\
\text { option. At the end, there is a space for commentaries. Here, the } \\
\text { scale of Session B: 4 - Much time; 3 - Quite some time; 2 - Some } \\
\text { time; 1 - Little time; 0 - No time. }\end{array}$ & $\begin{array}{l}\text { Indicate how much time you spend in the following activities, in your } \\
\text { current role, by signing the corresponding option. At the end, there is a } \\
\text { space for commentaries. Here, the scale of Session B: 4 - Much time; 3 - } \\
\text { Quite some time; 2 - Some time; 1 - Little time; 0 - No time. }\end{array}$ \\
\hline 1.1 & Does the patient history and physical examination and records it. & Carries out the patient history and physical examination and records it. \\
\hline 1.3 & Identifies and requests diagnostic tests and procedures. & Identifies and requests diagnostic exams and procedures. \\
\hline
\end{tabular}


Chart 1 (concluded)

\begin{tabular}{|c|c|c|}
\hline Question & Version after translation and cultural adaptation & $\begin{array}{l}\text { Version after reformulations according to the suggestions } \\
\text { of the judges }\end{array}$ \\
\hline 1.7 & $\begin{array}{l}\text { Communicates to the patient/family a plan of care and } \\
\text { response. }\end{array}$ & Communicates to the patient/family a plan of care and the responses. \\
\hline 1.10 & $\begin{array}{l}\text { Acts as a consultant to improve the attention to the patient } \\
\text { in nursing practice, based on the expertise in the field of } \\
\text { specialization. }\end{array}$ & $\begin{array}{l}\text { Acts as a consultant (specialized guidance) to improve the care of } \\
\text { the patient in nursing practice, based on the expertise in the field of } \\
\text { specialization. }\end{array}$ \\
\hline 1.12 & Coordinates an interdisciplinary plan for patient care. & Coordinates an interdisciplinary/interprofessional plan for patient care. \\
\hline 1.14 & $\begin{array}{l}\text { Facilitates the transit of the patient between the many } \\
\text { services of the health system. }\end{array}$ & $\begin{array}{l}\text { Facilitates the flow of the patient between the many services of the } \\
\text { health system. }\end{array}$ \\
\hline 2.2 & $\begin{array}{l}\text { Contributes, consults, or collaborates with other health } \\
\text { professionals in recruiting and retention activities. }\end{array}$ & $\begin{array}{l}\text { Contributes, consults, or collaborates with other health professionals in } \\
\text { recruiting and retention activities (follow up of the care practice of the } \\
\text { professional during a certain period of time for the definitive hiring and/ } \\
\text { or approval of internships in the public service). }\end{array}$ \\
\hline 2.3 & $\begin{array}{l}\text { Participates in the strategic planning of the service, } \\
\text { department, or hospital. }\end{array}$ & $\begin{array}{l}\text { Participates in the strategic planning of the service, department, } \\
\text { management, administration, hospital, or health system. }\end{array}$ \\
\hline 2.7 & Acts as a mentor. & Acts as a mentor/tutor/preceptor/advisor. \\
\hline 2.8 & Advocates in issues of nursing activities. & Defends the role of the nurse. \\
\hline 3.4 & $\begin{array}{l}\text { Acts as an informal educator for the team during direct care } \\
\text { activities. }\end{array}$ & Acts as an educator for the team during direct care activities. \\
\hline 3.5 & $\begin{array}{l}\text { Facilitates the professional development of the nursing team } \\
\text { through education. }\end{array}$ & $\begin{array}{l}\text { Facilitates the professional development of the nursing team using } \\
\text { continued/permanent education. }\end{array}$ \\
\hline 4.4 & $\begin{array}{l}\text { Uses research and integrates theory to practice, and } \\
\text { recommend changes in policy, based on research. }\end{array}$ & $\begin{array}{l}\text { Uses research and integrates theory to practice, and recommend } \\
\text { changes in strategies/policies, based on research. }\end{array}$ \\
\hline 4.5 & $\begin{array}{l}\text { Identifies the clinical data that must be collected and are } \\
\text { available in information systems for nursing and obstetric } \\
\text { researches and for quality assurance projects. }\end{array}$ & $\begin{array}{l}\text { Identifies the clinical data that must be collected, and which are } \\
\text { available in information systems/records for nursing and obstetric } \\
\text { researches and for quality assurance projects. }\end{array}$ \\
\hline 5.3 & $\begin{array}{l}\text { Acts as a consultant for individuals and groups within } \\
\text { professional or lay communities and other hospitals/ } \\
\text { institutions. }\end{array}$ & $\begin{array}{l}\text { Acts as a consultant for individuals and professional or lay groups and } \\
\text { other hospitals/institutions. }\end{array}$ \\
\hline 5.5 & $\begin{array}{l}\text { Represents the image of the nursing professionals in } \\
\text { institutional or community forums. }\end{array}$ & $\begin{array}{l}\text { Represents the image of the nursing professionals in institutional and/or } \\
\text { community forums. }\end{array}$ \\
\hline $\begin{array}{l}\text { Domain } \\
\text { 2: System } \\
\text { support }\end{array}$ & $\begin{array}{l}\text { Activities that give support to systems that promote } \\
\text { innovative care or facilitate the transit of the patient } \\
\text { throughout the health system. The role of defending the } \\
\text { rights of patients is also an important component of system } \\
\text { support. }\end{array}$ & $\begin{array}{l}\text { Activities that give support to systems that promote innovative care } \\
\text { and/or facilitate the flow of the patient throughout the health system. } \\
\text { The defense of the rights of patients is also an important component of } \\
\text { system support. }\end{array}$ \\
\hline $\begin{array}{l}\text { Domain 3: } \\
\text { Education }\end{array}$ & $\begin{array}{l}\text { Activities that involve the dissemination of current scientific } \\
\text { knowledge to the health team and to students, to improve } \\
\text { their knowledge. Furthermore, it includes health education, } \\
\text { the offering of information to the public, and allows them to } \\
\text { deal with the disease, while also promoting wellbeing. This } \\
\text { domain incorporates a wide variety of activities, including } \\
\text { the education of graduation and post-graduation students, } \\
\text { the informal development of professionals, the permanent } \\
\text { education of the team, and formal presentations for other } \\
\text { health professionals. }\end{array}$ & $\begin{array}{l}\text { Activities that involve the dissemination of current scientific knowledge } \\
\text { to the health team and to students, to improve their knowledge. } \\
\text { Furthermore, it includes health education, and provides information } \\
\text { to the public that allow them to deal with the disease, while also } \\
\text { promoting wellbeing. This domain incorporates a wide variety of } \\
\text { activities, including the education of graduation and post-graduation } \\
\text { students, the informal development of professionals, the permanent } \\
\text { education of the team, and formal presentations for other health } \\
\text { professionals. }\end{array}$ \\
\hline $\begin{array}{l}\text { Domain 5: } \\
\text { Publication } \\
\text { and } \\
\text { professional } \\
\text { leadership }\end{array}$ & $\begin{array}{l}\text { Activities that allow for the sharing and dissemination of } \\
\text { the knowledge of a field which go beyond the institutional } \\
\text { environment of an individual. It goes beyond the limits of the } \\
\text { workplace, demanding commitment with the profession and } \\
\text { with the public of the profession. The activities of this domain } \\
\text { aim to promote the profession of the nurse and the health } \\
\text { professionals. }\end{array}$ & $\begin{array}{l}\text { Activities that allow for the sharing and dissemination of the knowledge } \\
\text { of a field which go beyond the institutional environment of an } \\
\text { individual. It goes beyond the limits of the workplace, demanding } \\
\text { commitment with the profession and with the public of the profession. } \\
\text { The activities of this domain aim to promote nursing and health } \\
\text { professionals. }\end{array}$ \\
\hline
\end{tabular}

Table 3 shows the results of the time attribution carried out by professionals, with time destined to each activity, according to the domains of the scale.

When the dedication of the professional was evaluated according to the domain, it was found that nurses dedicate the most time to broad care (Quite some time - 142; Much time - 83), that is, to direct patient care; the lower amount of time was dedicated to publications and professional leadership (No time - 85), research (No time - 47), followed by education (No time - 37).

Regarding content validation, in the pre-test stage, there was a Cronbach's Alpha of 0.98 , which is considered excellent, and an intraclass correlation of 0.61 , considered to be substantial ${ }^{(18)}$.

The scale, translated into Brazilian Portuguese and ready for use, are attached to this article. 
Table 2 - Sociodemographic characteristics of the nurses

\begin{tabular}{|c|c|c|}
\hline Characteristics & $\mathbf{n}$ & $\%$ \\
\hline \multicolumn{3}{|l|}{ Sex } \\
\hline Female & 24 & 80 \\
\hline Male & 6 & 20 \\
\hline \multicolumn{3}{|l|}{ Age group (years) } \\
\hline $20-29$ & 1 & 3.3 \\
\hline $30-39$ & 24 & 80 \\
\hline $40-49$ & 4 & 13.3 \\
\hline$\geq 50$ & 1 & 3.3 \\
\hline \multicolumn{3}{|l|}{ Years of formal education } \\
\hline Graduation & 1 & 3.3 \\
\hline Post-graduation - Specialization & 25 & 83.3 \\
\hline Post-graduation - Residence & - & - \\
\hline MS & 4 & 13.3 \\
\hline PhD & - & - \\
\hline \multicolumn{3}{|l|}{ Field of action of the nurse } \\
\hline Obstetrics & 1 & 3.03 \\
\hline Clinical/assistance & 13 & 39.4 \\
\hline Professor & 1 & 3.03 \\
\hline Unit coordination & 9 & 27.3 \\
\hline Management & 7 & 21.2 \\
\hline District coordination & 1 & 3.03 \\
\hline Health instructor & 1 & 3.03 \\
\hline \multicolumn{3}{|l|}{ Time working in the profession (years) } \\
\hline$\leq 1$ & 4 & 13.3 \\
\hline $2-5$ & 3 & 10 \\
\hline $6-10$ & 16 & 53.3 \\
\hline $11-15$ & 2 & 6.66 \\
\hline $16-20$ & 2 & 6.66 \\
\hline$\geq 20$ & 3 & 10 \\
\hline
\end{tabular}

Note. $n$-Number.

Table 3 - Period dedicated to activities when compared to the domains

\begin{tabular}{lcccccc}
\hline Questão & $\begin{array}{c}\text { No } \\
\text { time } \\
\mathbf{n}(\%)\end{array}$ & $\begin{array}{c}\text { Little } \\
\text { time } \\
\mathbf{n}(\%)\end{array}$ & $\begin{array}{c}\text { Some } \\
\text { time } \\
\mathbf{n}(\%)\end{array}$ & $\begin{array}{c}\text { Quite } \\
\text { some time } \\
\mathbf{n}(\%)\end{array}$ & $\begin{array}{c}\text { Much } \\
\text { time } \\
\mathbf{n}(\%)\end{array}$ & Total \\
\hline Domain 1 - Direct broad care (14 questions) & $29(7.0)$ & $65(15.5)$ & $101(24.0)$ & $142(33.8)$ & $83(19.7)$ & 420 \\
Domain 2 - System support (9 questions) & $22(8.1)$ & $38(14.0)$ & $68(25.2)$ & $81(30.0)$ & $61(22.6)$ & 270 \\
Domain 3 - Education (6 questions) & $37(20.5)$ & $34(19.0)$ & $48(26.6)$ & $47(26.1)$ & $14(7.7)$ & 180 \\
Domain 4- Research (6 questions) & $47(26.1)$ & $43(24)$ & $46(25.5)$ & $39(21.6)$ & $5(2.8)$ & 180 \\
Domain 5 - Publication and professional leadership (6 questions) & $85(47.2)$ & $29(16.1)$ & $31(17.2)$ & $25(14.0)$ & $10(5.5)$ & 180 \\
Practical domains & & & & & & \\
D1 & $2(6.6)$ & $5(16.6)$ & $3(10.0)$ & $11(36.7)$ & $9(30.0)$ & \\
D2 & $0(-)$ & $4(13.3)$ & $9(30.0)$ & $12(40.0)$ & $5(16.6)$ & 30 \\
D3 & $2(6.6)$ & $7(23.3)$ & $10(33.3)$ & $6(20.0)$ & $5(16.6)$ & 3 \\
D4 & $6(20.0)$ & $8(26.6)$ & $8(26.6)$ & $7(23.3)$ & $1(3.3)$ & \\
D5 & $6(20.0)$ & $7(23.3)$ & $4(13.3)$ & $12(40.0)$ & $1(3.3)$ & \\
\hline
\end{tabular}

Note: $n$-Number; D-Domain.

\section{DISCUSSION}

Currently, there is an increase in the number of nursing validation studies, including the clinical validation of the phenomenon studied here. This confirms that nursing, as a science, has shown interest in the evaluation and measuring of its results. Measuring instruments have been used to aid content validation. They are tools to measure indicators and attribute numerical values to abstract concepts, using clinical evidences that will establish the rigor and authenticity of that which one is trying to measure ${ }^{(19)}$.

This study describes the process of transcultural translation and adaptation of the EMDF/EPA scale, attending to the methodological rigor prescribed in literature ${ }^{(11)}$. It showed a good internal consistency and psychometric properties that can measure how often nurses perform advanced practices.
In this process, it is necessary to adapt the language for the target population from a cultural and conceptual standpoint, while maintaining the objective of the original instrument ${ }^{(20)}$. The specialist committees had an agreement represented by a CVI of 1.00 in $93.48 \%$ of the questions, a being within values recommended in literature for committees made up by seven judges ${ }^{(13)}$.

The Brazilian version of the EMDF/EPA scale was submitted to a pre-test, which aims to maintain the meaning of the original version, improve understanding, and to find mistakes and/or problems in the application of the instrument being adapted ${ }^{(20)}$. The results of the pre-test of the scale showed that, in spite of the changes carried out in the content validation stage, by recommendation of the evaluative committee, there were no discrepancies in understanding, and high scores were reached.

It stands out that the analysis of the reliability of the scale showed that the Brazilian version reached satisfactory levels, which were confirmed by the fact that Cronbach's alpha was 0.98 , showing that the translated scale had excellent internal consistency, in addition to the 0.61 intraclass correlation. The adoption of these indicators sought to increase the precision of interpretation, since the coefficient Cronbach's alpha can be under the effect of the nature of data distribution and of sample size ${ }^{(13)}$. Similar results were achieved in the study in its original version, and were found to be reliable ${ }^{(10)}$.

Originally, the scale was developed to measure the advance practice roles carried out by nurses. The activities frequently cited by nurses, those to which they dedicate the largest part of their time, are those related to direct care to patients, that is, "hard work" activities, such as procedures, evaluations, data interpretation, provision of physical care, and patient guidance. Another domain that was commonly cited was that of system support, which includes activities that give support to systems that promote innovative care and/or facilitate the flow of the patient throughout the health system. The activities to which nurses dedicate less of their time are those related to publications and professional leadership, as well as those related to research, to which they dedicate no time.

These data corroborate literature, since, according to a revision developed, on one side, practices of patient assistance are the main activities developed by the nurses, followed by community practices; on the other hand, they dedicate less time to actions of coordination, management, and education ${ }^{(21)}$.

\section{Study limitations}

The limitations of this study are related to: difficulties in recruiting participants for an on-line data collection; the refusal of participants to make up the evaluative committee; and the fact 
that the pre-test collection took place in a single city and in a single setting of nursing practice. This is enough for a methodological study such as this one to achieve its goals, but does not allow for a generalization of results.

\section{Contributions to the Field of Nursing}

Considering the need for an instrument capable of measuring the advance practice nursing roles of Brazilian nurses, making the Modified Advanced Practice Nursing Role Delineation Tool, an instrument already available for Spanish speaking cultures, available in a Brazilian version, will be useful to identify the actions developed by Primary Health Care nurses in the country, subsidizing the implementation of strategies that contribute for the growth and formalization of advanced nursing practices in the national territory. As a result, this instrument will help improving the access of the population to health services and to the indicators related to patient and professional care.

\section{CONCLUSIONS}

This instrument was found to be culturally adapted and can be used in the country to identify the competences of the Primary Health Care Nurses to develop advanced nursing practices.

\section{REFERENCES}

1. Sánchez-Gómez MB, Santana SR, Gómez-Salgado J, Sánchez-Nicolás F, Moreno-Garriga C, Duarte-Clíments G. Benefits of advanced practice nursing for its expansion in the spanish context. Int J Environ Res Public Health. 2019;16(5):680. https://doi.org/10.3390/ijerph16050680

2. Paz EPA, Cunha CLF, Menezes EA, Santos GL, Ramalho NM, Werner RCD. [Práticas avançadas em enfermagem: rediscutindo a valorização do enfermeiro na atenção primária à saúde]. Enferm Foco [Internet]. 2018 [cited 2020 Jun 20];9(1):41-3. Available from: http://revista.Cofen.gov. br/index.php/enfermagem/article/view/1856

3. Aguirre-Boza F, Mackay MC, Pulcini J, Bryant-Lukosius D. Implementation strategy for advanced practice nursing in primary health care in Chile. Acta Paul Enferm. 2019;32(2):120-8. https://doi.org/10.1590/1982-0194201900018

4. Toso BRGO, Padilha MI, Breda KL. The euphemism of good practice or advanced nursing practice. Esc Anna Nery. 2019;23(3):e20180385. https://doi.org/10.1590/2177-9465-EAN-2018-0385

5. Gysin S, Sottas B, Odermatt M, Essig S. Advanced practice nurses and general practitioners first experiences with introducing the advanced practice nurse role to Swiss primary care: a qualitative study. BMC Family Practice. 2019;20(1):163. https://doi.org/10.1186/ s12875-019-1055-z

6. Miranda-Neto MV, Rewa T, Leonello VM, Oliveira MAC. Advanced practice nursing: a possibility for Primary Health Care?. Rev Bras Enferm. 2018;71(supl1):716-21. https://doi.org/10.1590/0034-7167-2017-0672

7. Bezerril MS, Chiavone FB, Mariz CM, Sonenberg A, Enders BC, Santos VE. Advanced practice nursing in Latin America and the Caribbean: context analysis. Acta Paul Enferm. 2018;31(6):636-43. https://doi.org/10.1590/1982-0194201800087

8. Laurant M, Van DBM, Wijers N, Watananirun K, Kontopantelis E, Van-Vught AJ. Nurses as substitutes for doctors in primary care: review. Cochrane Database Syst Rev. 2018;7:1-111. https://doi.org/10.1002/14651858.CD001271

9. Conselho Federal de Enfermagem. Cofen discute práticas avançadas de enfermagem na OPAS. DF: 2015 [Internet]. [cited 2020 Mar 01]. Available from: http://www.Cofen.gov.br/Cofen-discute-praticas-avancadas-de-enfermagem-na-opas_35458.html

10. Chang AM, Gardner GE, Duffield C, Ramis M. Advanced practice nursing role development: factor analysis of a modified role delineation tool. J Adv Nurs. 2011 ;68(6):1369-79. https://doi.org/10.1111/j.1365-2648.2011.05850

11. Beaton DE, Bombardier C, Guillemin F, Ferraz MB. Guidelines for the Process of Cross-Cultural Adaptation of Self-Report Measures. Spine. 2000;25(24):3186-91. https://doi.org/10.1097/00007632-200012150-00014

12. Pernambuco L, Espelt A, Magalhaes-Jr HV, Lima KC. Recommendations for elaboration, transcultural adaptation and validation process of tests in Speech, Hearing and Language Pathology. CoDAS. 2017;29(3):e20160217. https://doi.org/10.1590/2317-1782/20172016217

13. Souza AC, Alexandre NMC, Guirardello EB. Psychometric properties in instruments evaluation of reliability and validity. Epidemiol Serv Saude. 2017;26(3). https://doi.org/10.5123/S1679-49742017000300022

14. Oliveira JLC, Toso BRGO, Matsuda LM. Advanced practices for care management: reflections on the Brazilian Nursing. Rev Bras Enferm. 2018;71(4):2060-65. https://doi.org/10.1590/0034-7167-2017-0115

15. Alexandre NMC, Coluci MZO. Validade de conteúdo nos processos de construção e adaptação de instrumentos de medidas. Ciênc Saúde Colet[Internet]. 2011 [cited 2020 Oct 22];16(7):3061-8. Available from: https://www.scielo.br/pdf/csc/v16n7/06.pdf

16. Chang AM, Gardner GE, Duffield C, Ramis M. A Delphi study to validate an Advanced Practice Nursing tool. J Adv Nurs. 2010;66(10):2320-30. https://doi.org/10.1111/j.1365-2648.2010.05367

17. Mick DJ, Ackerman MH. Advanced practice nursing role delineation in acute and critical care: application of the strong model of advanced practice. Heart Lung. 2000;29(3):210-21. https://doi.org/10.1067/mhl.2000.106936

18. Silva RS, Paes ÂT. Teste de concordância Kappa. Einstein [Internet]. 2012 [cited 20210 Jan 01];10(4):165-6. Available from: http://apps. einstein.br/revista/arquivos/PDF/2715-165-166.pdf 
19. Leite SS, Áfio ACE, Carvalho LV, Silva JM, Almeida PC, Pagliuca LMF. Construction and validation of an Educational Content Validation Instrument in Health. Rev Bras Enferm. 2018;71(suppl 4):1635-41. https://doi.org/10.1590/0034-7167-2017-0648

20. Rodrigues EC, Cardoso MVLML, Campos FMC, Gazelle TGA, Nobre KSS, Oliveira NR. Content translation and validation of the Pediatric PIV Infiltration Scale into Brazilian Portuguese. Rev Bras Enferm. 2020;73(4):e20190300. https://doi.org/10.1590/0034-7167-2019-0300

21. Barbiani R, Dalla Nora CR, Schaefer R. Nursing practices in the primary health care context: a scoping review. Rev Latino-Am Enfermagem. 2016;24:e2721. https://doi.org/10.1590/1518-8345.0880.2721 